\title{
A Novel Reference Electrode for Application in Alkaline Polymer Electrolyte Membrane Fuel Cells
}

\author{
Rong Zeng,* Simon D. Poynton, Jamie P. Kizewski, Robert C.T. Slade, and John R. Varcoe \\ Chemical Sciences, University of Surrey, Guildford, Surrey GU2 7XH, United Kingdom
}

\begin{abstract}
An in situ fuel cell reference electrode (RE) consisting of a Pd-coated Pt wire exhibits stable potentials in alkaline polymer electrolyte membrane fuel cells (APEMFC). Results indicate that the overpotential and impedance of the anode are higher than those of the cathode in the cells tested (even at low currents); this is contrary to that found in proton-exchange membrane fuel cells (PEMFC) and shows that caution is required when translating prior understating of PEMFC to APEMFC. The working hypothesis is that there is flooding-derived mass transport loss at the anode (where water is electro-generated).
\end{abstract}

Keywords: alkaline membrane fuel cell; reference electrode; $\mathrm{Pd}-$-coated-Pt electrode; anode and cathode potentials; in-situ impedance spectrum

\section{Introduction}

Fuel cells will play a key role in the delivery of clean energy for a future sustainable society. Alkaline polymer electrolyte membrane fuel cells (APEMFC) are attracting worldwide interest as they offer the potential to utilise cheaper, more abundant, non-platinum catalysts [1,2]; there is increasing evidence of their ability to operate in the presence of carbonate anions $[3,4]$. To probe the processes occurring at the anode and cathode during fuel cell operation, a suitable reference electrode (RE) is 
required. There are reports on the use of a variety of RE types such as dynamic hydrogen electrodes (DHE [5-7]) and reversible hydrogen electrodes (RHE [8-10]) in proton-exchange membrane fuel cells (PEMFC) and solid oxide fuel cells; even carbon filaments can be used as pseudo-REs [11]. Construction of DHEs is complicated due to geometrical restrictions and high contact resistances; power is also needed to generate currents and the potential of DHEs are not stable for long periods of time in the absence of special precautions. For RHEs, pure hydrogen is usually supplied to a separated RE channel, where the potential can be affected by fluctuations in $\mathrm{H}_{2}$ partial pressures.

Pd is a classical hydrogen storage metal which absorbs hydrogen at ambient temperatures and pressures [12]. $\mathrm{Pd}($ core $) / \mathrm{Pt}($ shell) nanoparticles absorb hydrogen at the $\mathrm{Pt}-\mathrm{Pd}$ interface $\quad[13]$ and pure Pd and Pd-alloys [14] exhibit high activities towards the adsorption and oxidation of hydrogen in alkaline media. The above indicates that $\mathrm{Pd}$-adsorbed $-\mathrm{H}_{2}$ is retained for long periods of time, even on exposure to air, and this may be useful for the stabilisation of the potential of a Pt-wire RE. This report demonstrates the successful utilisation of Pd-coated-Pt wire RE in a APEMFC, which exhibits a stable potential that is insensitive to $\mathrm{H}_{2}$ concentration.

\section{Experimental details}

Pd was electrodeposited on the surface of $\mathrm{Pt}$ wire in aqueous $\left(\mathrm{NH}_{4}\right)_{2} \mathrm{PdCl}_{4}\left(0.04 \mathrm{~mol} \mathrm{dm}^{-3}\right)$ containing $\mathrm{HCl}\left(1 \mathrm{~mol} \mathrm{dm}^{-3}\right)$ and using a current of $30 \mathrm{~mA} \mathrm{~cm}^{-2}$ (geometric). After deposition, the $\mathrm{Pt} / \mathrm{Pd}$ electrode was charged at $30 \mathrm{~mA} \mathrm{~cm}{ }^{-2}$ for 15 min (cleaning procedure) and then $-30 \mathrm{~mA} \mathrm{~cm}{ }^{-2}$ for 15 $\min \left(\mathrm{H}\right.$ adsorption) for experiments in both aqueous $\mathrm{KOH}$ and $\mathrm{H}_{2} \mathrm{SO}_{4}$ electrolytes (both $1 \mathrm{~mol} \mathrm{dm}^{-3}$ ). The potentials, currents, and impedance spectra of the alkaline membrane electrode assembly (MEA) electrodes (Pt/C(20\%mass), $0.5 \mathrm{mg} \mathrm{cm}^{-2} \mathrm{Pt}$ loadings) vs. the $\mathrm{RE}$ were recorded using a 1470E/1455A 
CellTest system (Solartron Analytical, UK). The MEAs, radiation-grafted alkaline anion-exchange membranes (AAEM), alkaline ionomer, and fuel cell test procedures at $50^{\circ} \mathrm{C}$ were as previously reported $[15,16]$.

\section{Results and Discussion}

The $\mathrm{Pt} / \mathrm{Pd}$ wire (pre-treated at $-30 \mathrm{~mA} \mathrm{~cm}^{-2}$ for $\mathrm{H}$ adsorption) is denoted (Pt)PdH; the RE stability was tested in both aqueous $\mathrm{KOH}\left(1 \mathrm{~mol} \mathrm{dm}^{-3}\right)$ and $\mathrm{H}_{2} \mathrm{SO}_{4}\left(1 \mathrm{~mol} \mathrm{dm}^{-3}\right)$ without $\mathrm{H}_{2}(\mathrm{~g})$ purge. The (Pt)PdH RE showed two stable potentials with a switch from low to high potential after $10 \mathrm{~min}$. The potentials of the (Pt)PdH RE vs. SHE are summarised in Table 1 and compared with a $\mathrm{Pd} / \mathrm{H}_{2}$ electrode in the same electrolyte. The low potential plateau of the (Pt)PdH RE is similar to the $\mathrm{Pd} / \mathrm{H}_{2}$ benchmark and is ascribed to the $\alpha-\beta$ phase transition of the $\mathrm{Pd}-\mathrm{H}$ in the $\mathrm{Pd}$ layer. In the absence of a $\mathrm{H}_{2}(\mathrm{~g})$ purge, the absorbed $\mathrm{H}$ in Pd layer of the (Pt)PdH RE desorbed slowly until the switch to high potential was achieved. When the concentration of the hydrogen absorbed on Pd is $<2.2 \times 10^{-3} \mathrm{~mol} \mathrm{~cm}^{-3}$ [18], or concentration ratio of hydrogen to $\mathrm{Pd}$ is $<0.03$ [19], the $\alpha-\mathrm{PdH}$ phase is present. Salvarezza [20] reports that $\mathrm{H}$ atoms diffuse into bulk $\mathrm{Pd}$ when the cathodised potential $\left(E_{s}\right)$ is more positive than the reversible potential for the $\mathrm{H}_{2}$ evolution reaction $\left(E_{r}\right)$; when $E_{s}$ is more negative than $E_{r}$ the $\beta$-phase of PdH is formed. The (Pt)PdH RE showed only one stable potential of $772 \mathrm{mV} v s$. SHE when a high potential $-62 \mathrm{mV}$ vs. $\mathrm{Ag} / \mathrm{AgCl}\left(E_{s}>E_{r}\right.$ condition) was applied, using aqueous $\mathrm{H}_{2} \mathrm{SO}_{4}\left(1 \mathrm{~mol} \mathrm{dm}^{-3}\right)$ electrolyte, to absorb $\mathrm{H}_{2}$ into (Pt)Pd RE; this was very close to the high potential plateau (762 mV) of the (Pt)PdH RE after the original $-30 \mathrm{~mA} \mathrm{~cm}^{-2} \mathrm{H}$ adsorption. This confirms the high potential state of the (Pt)PdH RE was due to the $\alpha-\mathrm{PdH}$ at the $\mathrm{Pd} / \mathrm{Pt}$ interface [13] (provides a constant $\mathrm{H}$ environment and yields stable potentials as sensed by the internal Pt wire). 
The potential stability of the (Pt)PdH RE was also evaluated under fuel cell conditions. The (Pt)PdH REs were contacted to the surface of the AAEM (inactive area) at both the anode and cathode sides. A narrow channel was used to introduce $\mathrm{H}_{2}(\mathrm{~g})$ to the point of contact at anode side; this guaranteed that the low potential of the (Pt)PdH RE is stabilised by preventing desorption of $\mathrm{H}$ from the Pd layer (Fig. 1). Both the high potential and low potential states of the (Pt)PdH RE were stable during the test $(<10 \mathrm{mV}$ drift). It is vital that the high potential of the $(\mathrm{Pt}) \mathrm{PdH} \mathrm{RE}$ on the cathode side is stable, as supply of $\mathrm{H}_{2}(\mathrm{~g})$ is not possible. The potential in the inactive area is assumed to be uniform as the RE is located at least $3 \times$ AAEM thickness away from the the electrode edge [7, 21]. Fig. 2 shows the $V-I$ curve of a typical alkaline MEA and the recorded anode and cathode potentials. As the performance of the cell deteriorated, the overpotential of cathode increased slowly but the overpotential of anode increased dramatically (in a similar manner to the deterioration of the cell response).

Fig 3 shows the effect of AAEM thickness on performance. The cathode overpotential changed less than that of the anode, which decreased significantly from $550 \mathrm{mV}$ to $280 \mathrm{mV}$ at a current density of $320 \mathrm{~mA} \mathrm{~cm}^{-2}$ when the AAEM thickness decreased from $160 \mu \mathrm{m}(2 \times \mathrm{S} 80)$ to $20 \mu \mathrm{m}(\mathrm{S} 20) ; R_{\text {cell }}$ decreased from $0.46 \Omega \mathrm{cm}^{2}$ to $0.28 \Omega \mathrm{cm}^{2}$, equivalent to only $42 \mathrm{mV}$ less at this current density. Hence, the lower anode overpotential contributed more to the superior performance with the thinner AAEM than the ohmic loss. This is consistent with enhanced back diffusion of water from the anode to cathode with the thinner AAEM resulting in less anode flooding; this hypothesis is different to the one previously proposed, which had used the assumption that the anode overpotentials are insignificant compared to the cathode overpotentials (typical with PEMFC) [22]. Typical a.c. impedance spectra are presented in Fig 4. They confirm the d.c. results above in that the anode impedances are larger in magnitude than those of the cathode. The resistance deduced from the medium frequency anode 
impedance arc did not decrease in a manner consistent with a charge transfer process (unlike the cathode response) so interferences from mass transport phenomena are suspected.

\section{Conclusion}

Initial results, obtained using a new concept Pd-coated Pt wire reference electrode, suggest that the significant performance losses in alkaline polymer electrolyte membrane fuel cells (APEMFC) can originate at the anode. This is atypical behaviour when compared to proton-exchange membrane fuel cells (PEMFC) where the cathode is normally the primary source of performance losses: The common assumption that prior knowledge of traditional PEMFC can be directly translated to APEMFC therefore requires caution. The proposed hypothesis is that water generation at the anode of APMFC causes flooding and mass transport impedances; this is alleviated with the use of thinner alkaline membranes, which facilitates back transport of water to the cathode.

\section{Acknowledgement}

The authors thank the Engineering and Physical Sciences Research Council (UK, Grant EP/F027524/1) and the Defence Science and Technology Laboratory for funding. Prof. Anthony Kucernak (Imperial College) is thanked for discussions on aspects of reference electrodes.

\section{References}

[1] Sh. F. Lu, J. Pan, A. Huang, L. Zhuang, J. T. Lu, Proc. Natl. Acad. Sci. 105 (2008) 20611.

[2] S. D. Poynton, J. P. Kizewski, R. C.T. Slade, J. R. Varcoe, Solid State Ionics 181 (2010) 219.

[3] L. A. Adams, S. D. Poynton, C. Tamain, R. C. T. Slade, J. R. Varcoe, Chem. Sus. Chem. 1 (2008) 
79.

[4] M. Unlu, J. Zhou, P. A. Kohl, Electrochem. Solid-State Lett. 12 (2009) B27.

[5] Z. Siroma, R. Kakitsubo, N. Fujiwara, T. Ioroi, SI. Yamazaki, K. Yasuda, J. Power Sources 156 (2006) 284.

[6] K. Furukawa, K. Makino, K. Okajima, H. Minakuchi, Y. Okano, M. Sudoh, Int. J. Energy Res. 29 (2005) 1073.

[7] G. Li, P. G. Pickup, Electrochim. Acta 49 (2004) 4119.

[8] D. Gerteisen, T. Heilmann, C. Ziegler, J. Power Sources 177 (2008) 348.

[9] S. Uhm, S. T. Chung, J. Lee, J.Power Sources 178 (2008) 34.

[10] Q. Shen, M. Hou, D. Liang, Zh. M. Zhou, X. J. Li, Zh. G. Shao, B. L. Yi, J. Power Sources 189 (2009) 1114.

[11] H. Kuhna, B. Andreaus, A. Wokaun, G. G. Scherer, Electrochim. Acta 51 (2006) 1622.

[12] J. Volkl, in: G. Alefeld, J. Volkl (Eds), Hydrogen in Metals I, Springer-Verlag, Berlin, 1978, p1

[13] H. Kobayashi, M. Yamauchi, H. Kitagawa, Y. Kubota, K. Kato, M. Takata, J. Am. Chem. Soc. $130(2008) 1818$.

[14] M. Cristina F. Oliveira, Electrochim. Acta 53 (2008) 8138.

[15] J. R. Varcoe, R. C. T. Slade, Electrochem. Comm. 8 (2006) 839.

[16] J. R. Varcoe, R. C. T. Slade, E. L. H. Yee, Chem. Commun. (2006) 1428.

[17] M. Fleischmannt, J. N. Hiddlestont, J. Sci. Instru. (J. Phys. E) 1 (1968) 667.

[18] P. Millet, M. Srour, R. Faure, R. Durand, Electrochem. Comm. 3 (2001) 478.

[19] T-H. Yang, Su-Il Pyun, Electrochim. Acta. 41 (1996) 843.

[20] R. C. Salvarezza, M. C. Montemayor, E. Fatas, A.J. Arvia, J. Electroanal. Chem. 313 (1991) 291. 
[21] S. B. Adler, B. T. Henderson, M. A. Wilsona, D. M. Taylora, R. E. Richards, Solid State Ionics $134(2000) 35$.

[22] J. R. Varcoe, R. C. T. Slade, G. L. Wright, Y. L. Chen, J. Phys. Chem. B 110 (2006) 21041 
Fig. 1. The stability of the (Pt)PdH reference electrode under fuel cell conditions (open circuit): $T_{\text {cell }}=$ $50^{\circ} \mathrm{C}$, flow rates $\left(\mathrm{H}_{2}\right.$ and $\left.\mathrm{O}_{2}\right)=400 \mathrm{~cm}^{3} \mathrm{~min}^{-1}, \mathrm{RH}=100 \%$, and no back pressurisation.

Fig. 2. The polarization curve and the anode and cathode potentials (vs. (Pt)PdH RE) recorded with a scan rate of $5 \mathrm{mV} \mathrm{s}^{-1}$ for a APEMFC containing $2 \times \mathrm{S} 80(80 \mu \mathrm{m}$ thick) alkaline membranes. Test conditions are the same as Figure 2.

Fig. 3. The effect of membrane thickness on the APMFC performance. The RE and other cell and test conditions are the same as Figure 2. Error bars indicate the range of potentials measured in $10 \mathrm{~min}$ under constant current discharge.

Fig. 4. The impedance spectra of (a) anode and (b) cathode. The APEMFC and test condition are the same as Figure 2. 
Table $1 \mathrm{~A}$ comparison of the low and high potential responses of the $(\mathrm{Pt}) \mathrm{PdH}$ reference electrode with the potentials of the $\mathrm{Pd} / \mathrm{H}_{2}$ system.

\begin{tabular}{|c|c|c|c|}
\hline Electrolyte & $\begin{array}{c}\text { Potential of Pd/ } \mathrm{H}_{2} \text { vs. SHE } \\
{[17]}\end{array}$ & $\begin{array}{c}\text { Mean low potential } \\
(\mathrm{Pt}) \mathrm{PdH} v s . \mathrm{SHE}\end{array}$ & $\begin{array}{c}\text { Mean high potential } \\
(\mathrm{Pt}) \mathrm{PdH} \text { vs. SHE }\end{array}$ \\
\hline $\begin{array}{c}\mathrm{H}_{2} \mathrm{SO}_{4} \\
\left(\mathrm{aq}, 1 \mathrm{~mol} \mathrm{dm}^{-3}\right)\end{array}$ & $+32 \mathrm{mV}^{*}$ & $+36 \mathrm{mV}$ & $+761 \mathrm{mV}$ \\
\hline $\begin{array}{c}\mathrm{KOH} \\
\left(\mathrm{aq}, 1 \mathrm{~mol} \mathrm{dm}^{-3}\right)\end{array}$ & $-776 \mathrm{mV}^{*}$ & $-725 \mathrm{mV}$ & $+177 \mathrm{mV}$ \\
\hline
\end{tabular}

* Corrected for $\mathrm{H}^{+}$concentrations. 


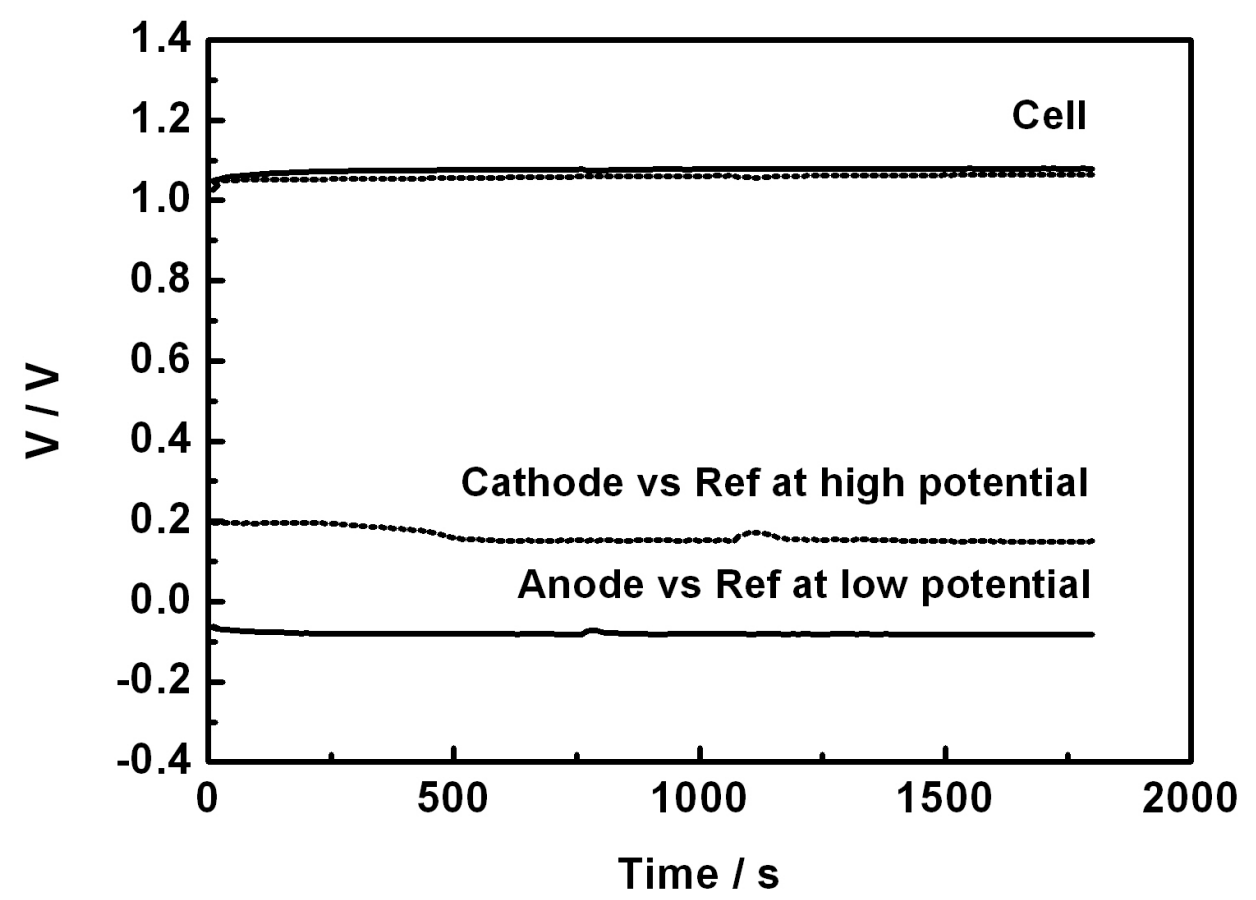

Fig. 1 


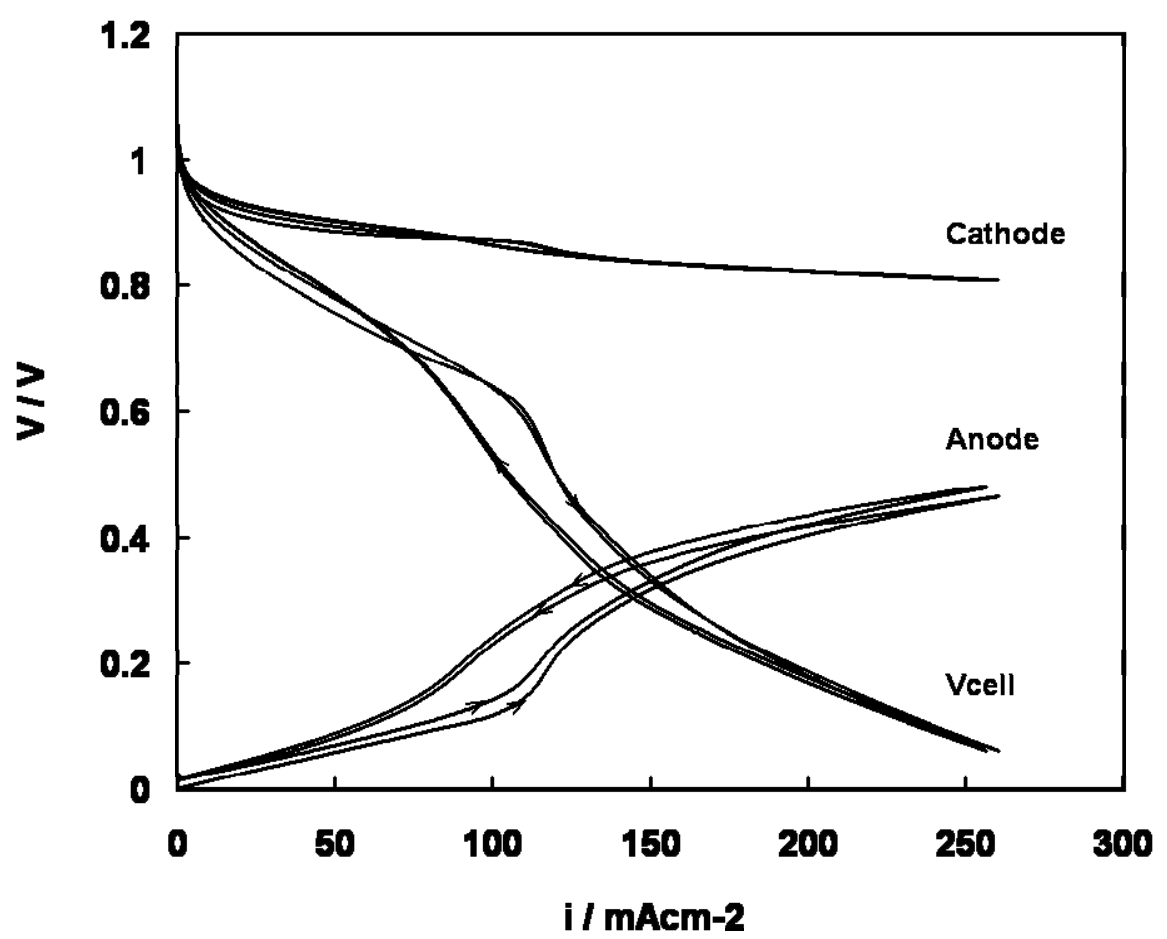

Fig. 2 


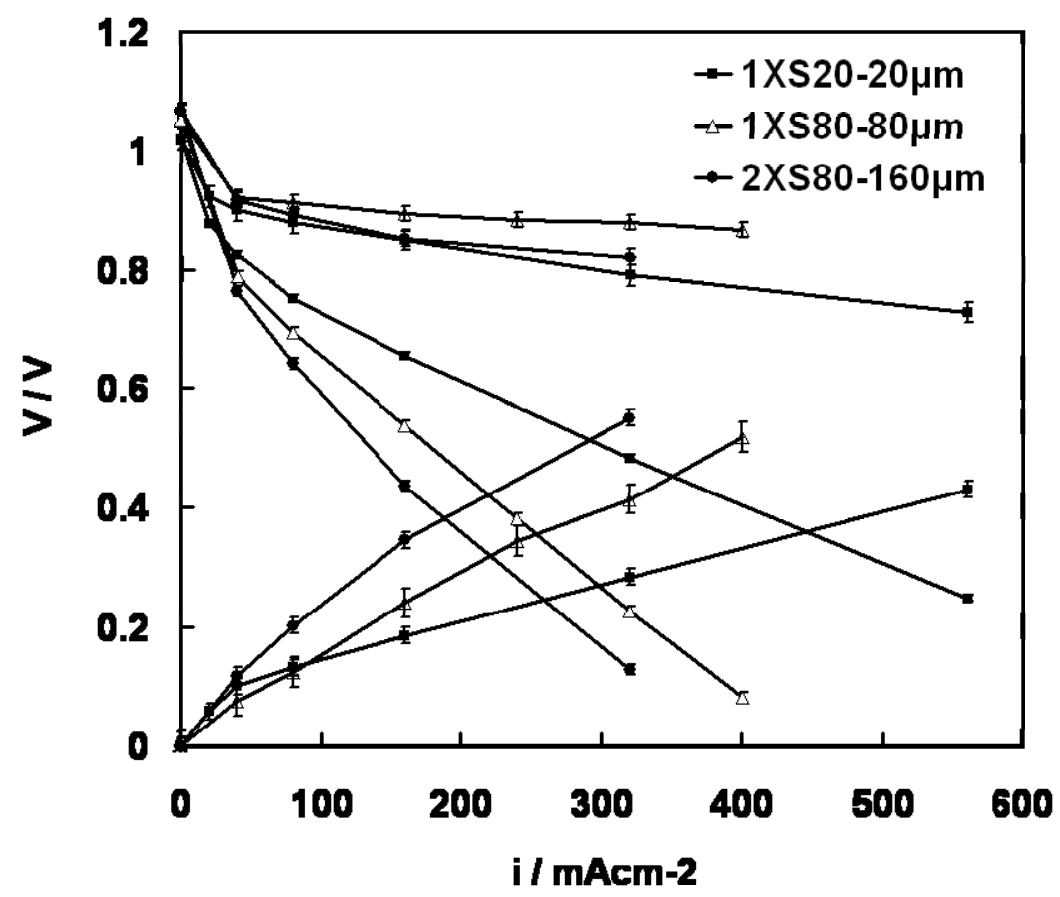

Fig. 3 

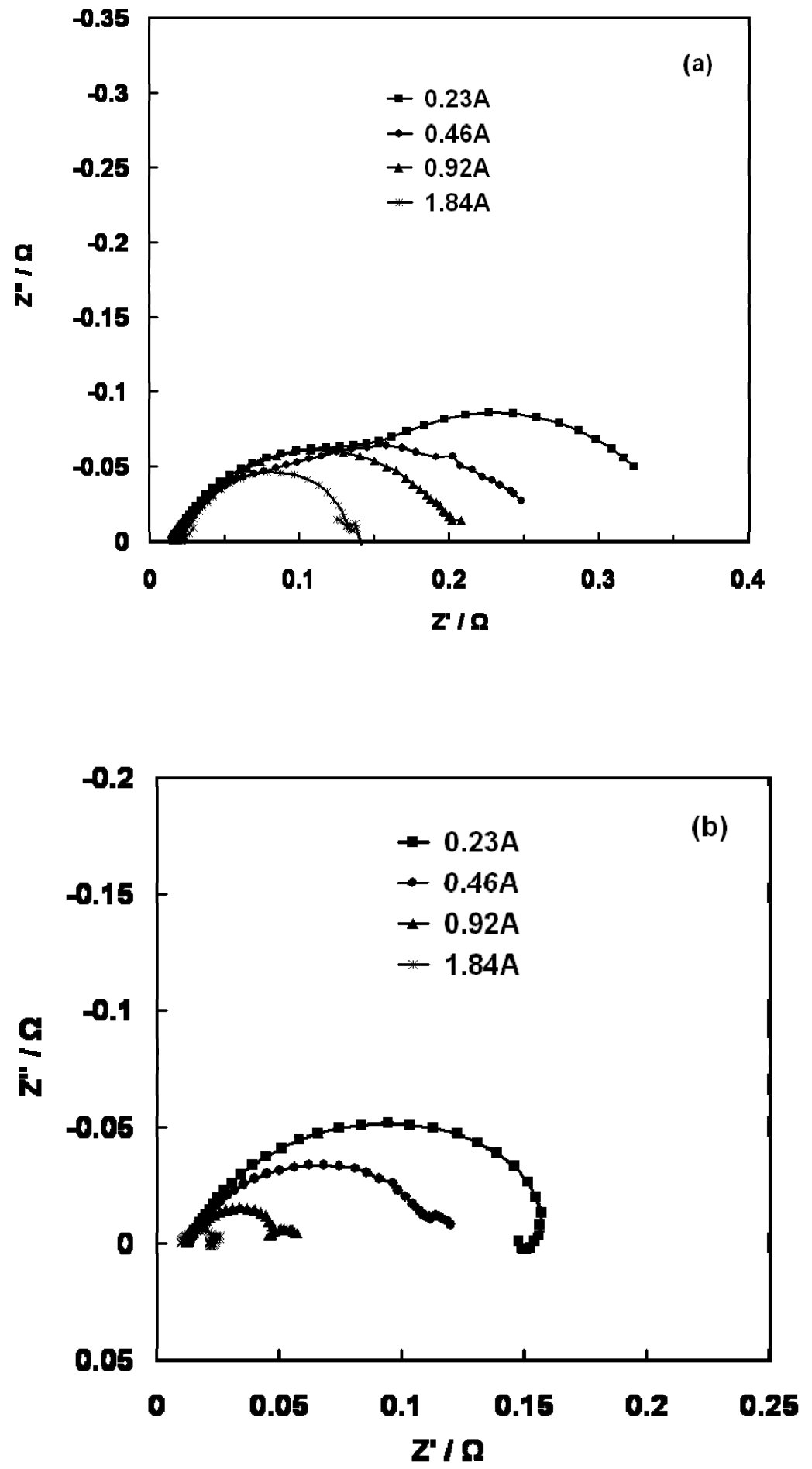

Fig. 4 